University of Nebraska - Lincoln

DigitalCommons@University of Nebraska - Lincoln

USDA National Wildlife Research Center - Staff Publications
U.S. Department of Agriculture: Animal and Plant Health Inspection Service

2012

\title{
Freshwater Clams As Bioconcentrators of Avian Influenza Virus in Water
}

Kathryn P. Huyvaert

National Wildlife Research Center, Kate.Huyvaert@ColoState.edu

Jenny S. Carlson

USDA/APHIS/WS National Wildlife Research Center

Kevin T. Bentler

National Wildlife Research Center, kevin.t.bentler@aphis.usda.gov

Kacy R. Cobble

National Wildlife Research Center

Dale L. Nolte

USDA-APHIS-Wildlife Services, Dale.L.Nolte@aphis.usda.gov

See next page for additional authors

Follow this and additional works at: https://digitalcommons.unl.edu/icwdm_usdanwrc

Huyvaert, Kathryn P.; Carlson, Jenny S.; Bentler, Kevin T.; Cobble, Kacy R.; Nolte, Dale L.; and Franklin, Alan B., "Freshwater Clams As Bioconcentrators of Avian Influenza Virus in Water" (2012). USDA National Wildlife Research Center - Staff Publications. 1150.

https://digitalcommons.unl.edu/icwdm_usdanwrc/1150

This Article is brought to you for free and open access by the U.S. Department of Agriculture: Animal and Plant Health Inspection Service at DigitalCommons@University of Nebraska - Lincoln. It has been accepted for inclusion in USDA National Wildlife Research Center - Staff Publications by an authorized administrator of DigitalCommons@University of Nebraska - Lincoln. 


\section{Authors}

Kathryn P. Huyvaert, Jenny S. Carlson, Kevin T. Bentler, Kacy R. Cobble, Dale L. Nolte, and Alan B. Franklin 


\title{
Band Encounters of Wintering European Starlings Captured in Kansas, Nebraska, and Texas
}

H. JEFFREY HOMAN, U.S. Department of Agriculture, Animal and Plant Health Inspection Service, Wildlife Services, National Wildlife Research Center, Bismarck, ND, USA

JAMES R. THIELE, U.S. Department of Agriculture, Animal and Plant Health Inspection Service, Wildlife Services, Lincoln, NE, USA

GARRETT W. UNREIN, U.S. Department of Agriculture, Animal and Plant Health Inspection Service, Wildlife Services, Lincoln, NE, USA

SHANNON M. GAUKLER, Department of Biological Sciences, North Dakota State University, Fargo, ND, USA ANTHONY A. SLOWIK, U.S. Department of Agriculture, Animal and Plant Health Inspection Service, Wildlife Services, National Wildlife Research Center, Bismarck, ND, USA

LINDA B. PENRY, U.S. Department of Agriculture, Animal and Plant Health Inspection Service, Wildlife Services, National Wildlife Research Center, Bismarck, ND, USA

GEORGE M. LINZ, U.S. Department of Agriculture, Animal and Plant Health Inspection Service, Wildlife Services, National Wildlife Research Center, Bismarck, ND, USA

\begin{abstract}
European starlings (Sturnus vulgaris) are agricultural and societal pests in the U.S., thus, understanding their migratory behavior is of practical importance to resource managers. We leg-banded starlings and used publicly reported encounters with them to estimate migration distances traveled by wintering populations to reach their reproductive territories. We captured and banded 9,939 starlings at 6 sites between November and February 2005-2010 in 3 states. We banded birds in industrial areas surrounding Omaha, Nebraska, and at cattle feedlots in central Kansas $(n=2)$ and the Texas Panhandle $(n=3)$. Banding sites were associated with wintering aggregations that caused agricultural or urban conflicts. Thirty band encounters $(0.3 \%)$ occurred between April-August, which we defined as the reproductive period. The median number of days between date of banding and date of encounter was $170\left(n=28, \mathrm{Range}^{6} 66-862 ; \mathrm{Q}_{3}-\mathrm{Q}_{1}=\right.$ $361)$. We categorized encounters as either regional $(\geq 80 \mathrm{~km})$ or local $(<80 \mathrm{~km})$. Median distance of regional encounters was $421 \mathrm{~km}\left(n=16\right.$, Range: $\left.125-1,384 ; \mathrm{Q}_{3}-\mathrm{Q}_{1}=456\right)$; median distance of local encounters was $24 \mathrm{~km}(n=14, \mathrm{Range}: 12-75$, $\left.\mathrm{Q}_{3}-\mathrm{Q}_{1}=5\right)$. The regional encounters occurred on a median bearing from the banding sites $+12^{\circ}$ from true north $(n=16$, Range: $\left.-18-67 ; Q_{3}-Q_{1}=26\right)$. Starlings are renowned and persistent pests, and the birds from our study areas probably contributed to agricultural and urban conflicts in several states.
\end{abstract}

KEY WORDS Band encounters, European starling, Kansas, migration, Nebraska, Sturnus vulgaris, Texas, vertebrate pest, wintering starlings.

European starlings (Sturnus vulgaris) are abundant throughout most of the contiguous U.S., with an estimated breeding population of 200 million (Feare 1984). Starlings are agricultural and societal pests with an economic impact approaching U.S. \$1 billion dollars annually (Pimentel et al. 2005). They may also be biological vectors for several pathogens (LeJeune et al. 2001, Carlson et al. 2011). Migratory behavior of starlings in the eastern and midwestern portions of the U.S. is well understood because of the numerous bird-banding stations in these regions (Dolbeer 1982). However, for most of the central region of the U.S., banding data are sparse and little is known about migratory patterns.
Confinement cattle-feeding operations, which abound in the central region of the U.S., have chronic conflicts with starlings (Besser et al. 1968, Depenbusch et al. 2011). Similarly, urban environments often harbor winter roosts of starlings that deface and degrade city infrastructure (Potts 1967, Homan et al. 2006, Linz et al. 2007, Bernardi et al. 2009). Resource managers need to understand migratory patterns of starlings to assess economic costs and most efficiently allocate management efforts.

We banded starlings at cattle feedlots in rural Texas and Kansas and in the urban environment of Omaha, Nebraska. Our objectives were to: 1) estimate the distances that banded starlings traveled from their 
wintering grounds to reach their presumed nesting areas, and 2) estimate the proportion of wintering starlings that were migrants. Our data provide a baseline understanding of starling migration patterns in the central U.S., and by implication, the potential scope and breadth for regional conflicts.

\section{METHODS}

\section{Banding}

We captured birds using mist nets and drop-in decoy traps. Five of the banding sites were located at cattle feedlots in Kansas $(n=2)$ and Texas $(n=3)$. Managers of these facilities had asked the USDA APHIS Wildlife Services program for assistance with starling infestations. The urban banding site was comprised of several substations located in commercial-industrial zones surrounding Omaha, Nebraska, and at outlying feedlots $<40 \mathrm{~km}$ from Omaha. Most bandings in Omaha occurred in the commercial-industrial zones at food processing facilities and grain storage sites. All birds were banded with \#2 U.S. Fish and Wildlife Service aluminum bands and released immediately onsite. The banding data were sent electronically to the U.S. Geological Survey (USGS) Bird Banding Laboratory. The laboratory notified us of recoveries (encounters) and provided information on the date, latitude and longitude, and circumstances under which the bands were recovered. We used only publicly recorded encounters. We did not use our own band encounters or encounters reported by bird-banding stations because these are considered nonrandom encounters and potentially create bias in the analysis of distances and distributions (Dolbeer 1978). We defined the winter period as the months between November and February and the reproduction period as April to
August. We did not use band encounters from March or September to October, which are periods of high migratory activity for starlings (Dolbeer 1982).

\section{Data Analysis}

We categorized encounters as either regional $(\geq 80$ $\mathrm{km})$ or local $(<80 \mathrm{~km})$ to facilitate comparisons with another study conducted on starlings in the Central Flyway (Royall and Guarino 1976). The 80-km distance is probably near the limit that starlings fly daily to reach foraging grounds (Hamilton and Gilbert 1969, Homan et al. 2010). Distances from banding sites to encounter sites were measured using the haversine-distance formula (Sinnott 1984). Number of days between banding and recovery and the initial bearing from the banding sites to the encounter sites were calculated using spreadsheet formulas (Veness 2010). The median was used to describe central tendency of the data, and the difference between the first and third statistical quartiles $\left(Q_{1}, Q_{3}\right)$ was used for measuring dispersion. Coordinates of recoveries and banding sites were entered into a Geographic Information System (GIS) for visual display.

\section{RESULTS}

We captured and banded 9,939 European starlings between November and February 2005-2010. Thirty bands $(0.3 \%)$ were encountered between April and August 2006-2010 (Table 1). Two of the band returns did not include the day of the encounter but included the month. The median distance for all encounters was $127 \mathrm{~km}(n=30$, Range: $12-1,384 ; \mathrm{Q} 3-\mathrm{Q} 1=427)$. Of the 30 encounters, $16(53 \%)$ were categorized as regional and $14(47 \%)$ were local (Figure 1). The median distance of regional encounters was $421 \mathrm{~km}(n$ =16, Range: 125-1,384; Q3-Q1 = 456); whereas the

Table 1. Number of wintering European starlings banded (N) and reported to the USGS Bird Banding Laboratory as encountered (n) during the reproductive period (April-August) from multi-year banding projects conducted in 3 states between November and February 2005-2010 in the central U.S.

\begin{tabular}{|l|l|l|l|l|l|l|l|l|l|l|}
\hline \multicolumn{2}{|c|}{} & \multicolumn{2}{l}{ Total } & \multicolumn{2}{l|}{$\geq 80 \mathrm{~km}$} & \multicolumn{2}{l|}{$<80 \mathrm{~km}$} \\
\hline State & Years & $N$ & $n$ & $\% *$ & $n$ & $\%$ & $\mathrm{~km}$ & $n$ & $\%$ & $\mathrm{~km}$ \\
\hline KS & $2006-2008$ & 5,678 & 21 & 0.4 & 10 & 48 & 488 & 11 & 52 & 21 \\
\hline NE & $2005-2010$ & 3,590 & 7 & 0.2 & 4 & 57 & 449 & 3 & 43 & 37 \\
\hline TX & $2008-2009$ & 601 & 2 & 0.3 & 2 & 100 & 520 & 0 & 0 & - \\
\hline Total & & 9,939 & 30 & & 16 & 53 & 485 & 14 & 47 & 29 \\
\hline
\end{tabular}

$*: \%=(n / N) * 100$ 


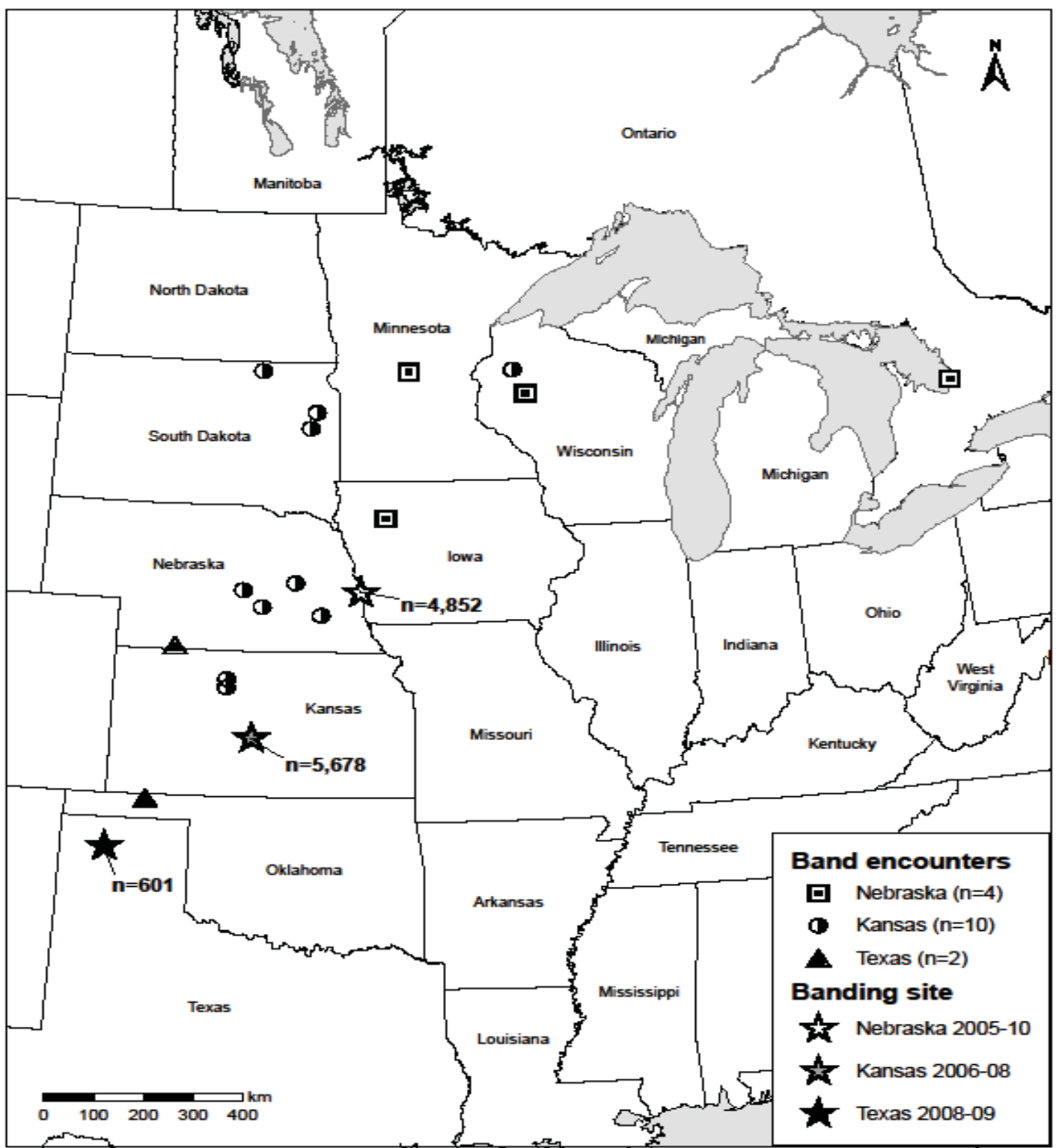

Figure 1. Band encounters $(\mathrm{n}=16)$ from 9,939 European starlings banded at study sites in Kansas, Nebraska and Texas between November and February 2005-2010 and encountered $\geq 80 \mathrm{~km}$ from banding sites between April and August 2006-2010. The numbers by the banding sites represent the number of starlings banded.

median for local encounters was $24 \mathrm{~km}(n=14$, Range: 12-75, Q3-Q1 = 5). The median number of days between date of banding and date of recovery was 170 ( $n=28$, Range: 66-862; Q3-Q1 = 361). Regional encounters occurred on a median bearing from the banding sites that was $+12^{\circ}$ from true north $(n=16$, Range: -18-67; Q3-Q1 = 26).

\section{DISCUSSION}

The wintering populations at our banding sites were composed of nearly even percentages of local and regional birds, as defined by our classification crite- rion. We believe this outcome indicated the actual compositional mix of regional and local birds from our sampled populations. By restricting our analysis to publicly reported band encounters, we created a nearly even sampling effort over the region, thus closely approximating random data collection, which strengthens statistical interpretation. Kessel (1953) estimated that the wintering population of starlings in Ithaca, NY, was comprised of $62 \%$ migrants, a percentage roughly comparable to our estimate of $53 \%$. Studies in other regions of the eastern U.S. have shown wintering populations of starlings to 
consist of even higher numbers of migrants (Kalmbach 1932, Thomas 1934); for example, Kalmbach (1932) estimated that $77 \%$ of the wintering population in Washington, D.C. was migrants. We had speculated a priori that the central region of the U.S. should have greater proportions of migrants, because of lower human-population densities and average annual rates of precipitation. Both of these factors should reduce the availability of nesting cavities (anthropogenically and naturally) making migration from the wintering area more likely. Dolbeer (1982) suggested that as the latitude decreases (especially $\leq 40^{\circ} \mathrm{N}$ ) a corresponding increase should occur in proportions of non-migrating starlings in wintering populations. A combination of milder climatic conditions, behavioral adaptations to cold stress, and a general reluctance to depart reproductive territories could cause this phenomenon. Variability among years in winter severity can also affect proportions of migrants and non-migrants in a wintering population (Royall and Guarino 1976). We could not determine proportions of wintering populations from the analyses of either Dolbeer (1982) or Royall and Guarino (1976).

Starlings in the eastern and Midwestern sections of the U.S. migrated about $240 \mathrm{~km}$ between their reproductive territories and wintering grounds, which makes them short-distance migrants (Dolbeer 1982). The distanced traveled by migrating birds that we banded was $420 \mathrm{~km}$, practically twice the $240-\mathrm{km}$ estimate. However, this still places the starling in the category of short-distance migrant. The variation in distance traveled by our birds was large with the farthest encounter at $1,400 \mathrm{~km}$ from the banding site. This distance was similar to the most northward encounter recorded by Royall and Guarino (1976). Under the assumption that we were sampling from a wintering population perhaps numbering in the tens of millions, large numbers of starlings spread throughout the central U.S. to reach their breeding territories. The 16 regional encounters should be thought of as a skeletal framework of the summer distribution of starlings wintering in our study areas. Indeed, Kessel (1953, see Figure 5, parts $a$ and $b$ ), using banding sites in proximity to our Kansas banding sites, showed nearly the same distribution pattern and declination from true north that we found in our analysis. It is not known whether the southwest-northeast line of spring migratory movement is a result of topography, as suggested by Kessel (1953), or an inherent behavior (Royall and Guarino 1976).

\section{MANAGEMENT IMPLICATIONS}

Conflicts with starlings have been reported in all states within the central U.S. migratory corridor. At the conclusion of the reproductive season, most pre-migratory and migratory flocks of starlings become involved in wildlife conflicts of some kind, whether in urban areas or at agricultural endeavors (e.g., fruit orchards, livestock facilities). The banding data from wintering populations in Kansas, Nebraska, and Texas indicate that these populations contribute to the regional damage caused annually by starlings throughout the central U.S. A concerted management effort among states (particularly, during the spring migration period when food availability is low and livestock facilities are heavily exploited) may increase management efficiency and lead to a reduction of regional impacts.

\section{ACKNOWLEDGMENTS}

We thank Kansas Wildlife Services, Nebraska Wildlife Services, Texas Wildlife Services and the USGS Bird Banding Laboratory for their help with our studies. We also thank the following individuals for their support and assistance with our project: J Carlson, A. Galle, H. Ladd, and C. Salter. The research was done under Study Protocols QA-1324, QA-1414, and QA1592 approved by the National Wildlife Research Center, Fort Collins, Colorado. The Study Director was Dr. H. J. Homan for QA-1324 and QA-1592. The Study Director for QA-1414 was Dr. G.M. Linz.

\section{LITERATURE CITED}

Bernardi, E., D. J. Bowden, P. Brimblecombe, H. Kenneally, and L. Morselli. 2009. The effect of uric acid on outdoor copper and bronze. Science of the Total Environment 407:2383-2389.

Besser, J. F., J. W. DeGrazio, and J. L. Guarino. 1968. Costs of wintering starlings and redwinged blackbirds at feedlots. Journal of Wildlife Management 32:179-180.

Carlson, J. C., A. B. Franklin, D. R. Hyatt, S. E. Pettit, and G. M. Linz. 2011. The role of starlings in the spread of Salmonella within concentrated animal feeding operations. Journal of Applied Ecology 48:479-486.

Depenbusch, B. E., J. S. Drouillard, and C. D. Lee. 2011. Feed depredation by European starlings in a Kansas feedlot. Human-Wildlife interactions 5:58-65. 
Dolbeer, R. A. 1978. Movement and migration patterns of red-winged blackbirds: a continental overview. Bird-Banding 49:17-34.

Dolbeer, R. A. 1982. Migration patterns for age and sex classes of blackbirds and starlings. Journal of Field Ornithology 53:28-46.

Feare, C. J. 1984. The starling. Oxford University Press, Oxford, England, UK.

Hamilton, W. J., and W. M. Gilbert. 1969. Starling dispersal from a winter roost. Ecology 50:886898.

Homan, H. J., G. M. Linz, G. W. Unrein, J. R. Thiele, and J. M. Hobbs. 2006. Movements of European starlings captured at a winter roost in Omaha, Nebraska. Proceedings of the North American Prairie Conference 20:79-82.

Homan, H. J., A. A. Slowik, L. B. Penry, M. J. Bodenchuk, R. L. Gilliland, and G. M. Linz. 2010. Local movements and patterns of site use by European starlings captured at 3 feedlots in the Texas Panhandle during winter 2008-2009. Proceedings of Vertebrate Pest Conference 24:250-256.

Kalmbach, E.R. 1932. Wintering starling roosts of Washington. Wilson Bulletin 44:65-75.

Kessel, B. 1953. Distribution of migration of the European starling in North America. Condor 55:49-67.

LeJeune J. T., T. E. Besser, and D. D. Hancock. 2001. Cattle water troughs as reservoirs of Escherichia coli 0157. Applied and Environmental Microbiology 67:3053-3057.

Linz, G. M., H. J. Homan, S. M. Gaukler, L. B. Penry, and W. J. Bleier. 2007. European starlings: a review of an invasive species with far-reaching impacts. Pages 378-386 in Managing vertebrate invasive species: proceedings of an international symposium. G. W. Witmer, W. C. Pitt, and K. A. Fagerstone, editors. USDA APHIS WS, National Wildlife Research Center, Fort Collins, CO, USA.

Pimentel, D., R. Zuniga, and D. Morrison. 2005. Update on the environmental and economic costs associated with alien-invasive species in the United States. Ecological Economics 52:273-288.

Potts, G. R. 1967. Urban starling roosts in the British Isles. Bird Study 14:25-42.
Royall, W.C., Jr., and J. L. Guarino. 1976. Movements of starlings banded in north-central Colorado 1960-74. North American Bird Bander 1:58-62.

Sinnott R. W. 1984. Virtues of the haversine. Sky and Telescope 68:159.

Thomas, E.S. 1934. A study of starlings banded at Columbus, Ohio. Bird-Banding 5:118-128.

Veness, C. 2010. Latitude-longitude spherical geodesy formulae and scripts. <http://www.movable-type. co.uk/scripts/latlong.html>. Accessed 18 May 2011. 